\title{
GROUND-PENETRATING RADAR STUDIES IN SVALBARD AIMED TO THE CALCULATION OF THE ICE VOLUME OF ITS GLACIERS
}

\author{
F. J. NAVARRO ${ }^{1 *}$, J. LAPAZARAN ${ }^{1}$, \\ A. MARTÍN-ESPAÑOL ${ }^{2,1}$, J. OTERO $^{1}$ \\ ${ }^{1}$ Departamento de Matemática Aplicada a las Tecnologías de la Información y \\ las Comunicaciones, Universidad Politécnica de Madrid, Spain. \\ ${ }^{2}$ School of Geographical Sciences, Bristol University, United Kingdom.
}

\begin{abstract}
During the period 1999-2014, the Group of Numerical Simulation in Sciences and Engineering of Universidad Politécnica de Madrid carried out many ground-penetrating radar campaigns in Svalbard, aimed to the study of glacier ice-thickness and the physical properties of glacier ice. The regions covered were Nordenskiöld Land, Wedel Jarlsberg Land, Sabine Land and Nordaustlandet. We here present a review of these works, focused on the aspects related to the estimate of the volume of individual glaciers and its extrapolation to the entire set of Svalbard glaciers, for which the authors estimate a total volume of $6700 \pm 835 \mathrm{~km}^{3}$, or $17 \pm 2 \mathrm{~mm}$ in sea-level equivalent.
\end{abstract}

Estudios de georradar en Svalbard orientados al cálculo del volumen de hielo de sus glaciares

RESUMEN. Durante el periodo 1999-2014, el grupo de Simulación Numérica en Ciencias e Ingeniería de la Universidad Politécnica de Madrid llevó a cabo numerosas campañas de georradar en Svalbard orientadas al estudio del espesor y las propiedades físicas del hielo de sus glaciares. Las regiones cubiertas abarcaron Nordenskiöld Land, Wedel Jarlsberg Land, Sabine Land y Nordaustlandet. Se presenta en este artículo una revisión de estos trabajos, centrada en los aspectos relativos al cálculo del volumen de hielo de glaciares individuales y su extrapolación al conjunto de glaciares de Svalbard, para el que los autores estiman un volumen de hielo de $6700 \pm 835 \mathrm{~km}^{3}$ o $17 \pm 2 \mathrm{~mm}$ en equivalente de nivel del mar.

Keywords: glacier, ground-penetrating radar, Svalbard, ice thickness, volume.

Palabras clave: glaciar, georradar, Svalbard, espesor de hielo, volumen. 
*Corresponding author. F. J. Navarro, Departamento de Matemática Aplicada a las Tecnologías de la Información y las Comunicaciones, Universidad Politécnica de Madrid, 28040 Madrid, Spain. E-mail: francisco.navarro@upm.es

\section{Introduction}

The set of about 211,000 glaciers on Earth contains less than $1 \%$ of the ice volume stored by the large ice sheets of Antarctica and Greenland. In spite of it, as the IPCC 2013 report (Stocker et al., 2013) has pointed out, the glaciers have currently a contribution to sea-level rise larger than that of the large ice sheets (27\% vs. $21 \%)$, and this trend is expected to continue at least during most of the $21^{\text {st }}$ century. This apparent paradox is due to the faster response time of the smaller glaciers to climate warming. For how long this larger contribution of glaciers will last depends on the total volume of ice stored by glaciers, which represents its potential contribution to sea-level rise. For this reason, there is a renewed interest in estimating the total ice volume stored by glaciers.

The ground-penetrating radar (GPR) is the most effective tool for determining the ice-thickness of glaciers and, as a derived computation, their ice volume. However, undertaking GPR campaigns is logistically demanding and costly. Consequently, icethickness data with sufficient coverage to estimate reliably the total ice volume are only available for a few hundreds of glaciers on Earth. It is therefore necessary to use other tools to estimate the ice volume of glaciers. The two alternative methods that have been used with this purpose are the volume-area (V-A) scaling relationships (Radić and Hock, 2010; Grindsted, 2013) and the physically-based methods relating the ice-thickness distribution with the glacier topography, mass balance and dynamics (Huss and Farinotti, 2012). These methods, however, still require the use of more accurate glacier volumes calculated from GPR-retrieved ice thickness, which are used as calibration dataset for deriving the scaling relationships or to adjust the free parameters of the physically-based models. We note that these two families of methods are also a usual tool for regional and global projections of glacier wastage, and corresponding sea-level rise, in response to climate scenarios (Radić et al., 2014; Huss and Hock, 2015).

\section{Geographical setting}

Svalbard (76-81 ${ }^{\circ} \mathrm{N}, 10-33^{\circ} \mathrm{E}$; Fig. 1$)$ is a heavily glacierized archipelago located in the Atlantic sector of the Arctic. Its climate is warmer than what we would expect from its high latitude. This is due to the net heat transport along the year by the oceanic currents (in particular, the western Spitsbergen current) and the winds, which, when low pressures dominate, bring over Svalbard mild and wet oceanic air. The Atlantic sector of the Arctic is a region highly vulnerable to climate warming (ACIA, 2005). A recent multi-model study suggests that Svalbard glaciers will contribute to sea-level rise, during the period 2006-2100, by 12.41 and $15.81 \mathrm{~mm}$ of sea-level equivalent (SLE) for climate scenarios RCP4.5 and RCP8.5, respectively (Radić et al., 2014), which represents dramatic volume losses by 55 and $70 \%$, respectively. 
The Svalbard ice mases include 1615 glaciers, covering $~ 33,922 \mathrm{~km}^{2}$ (Pfeffer et $a l ., 2014)$, which makes of this region one of the most heavily glacierized of the Arctic. Its glacierized area represents $\sim 18 \%$ of the area of the high Arctic glaciers, considering the latter as the set made up of Canadian Arctic-North, Svalbard and Jan Mayen, and Russian Arctic, according to the terminology of the Randolph Glacier Inventory (Pfeffer et al., 2014), and excluding the Greenland Ice Sheet and its peripheral glaciers. These numbers include the glaciers on Jan Mayen Island, at a more southern latitude, which has 48 glaciers with a total area of $120 \mathrm{~km}^{2}$.

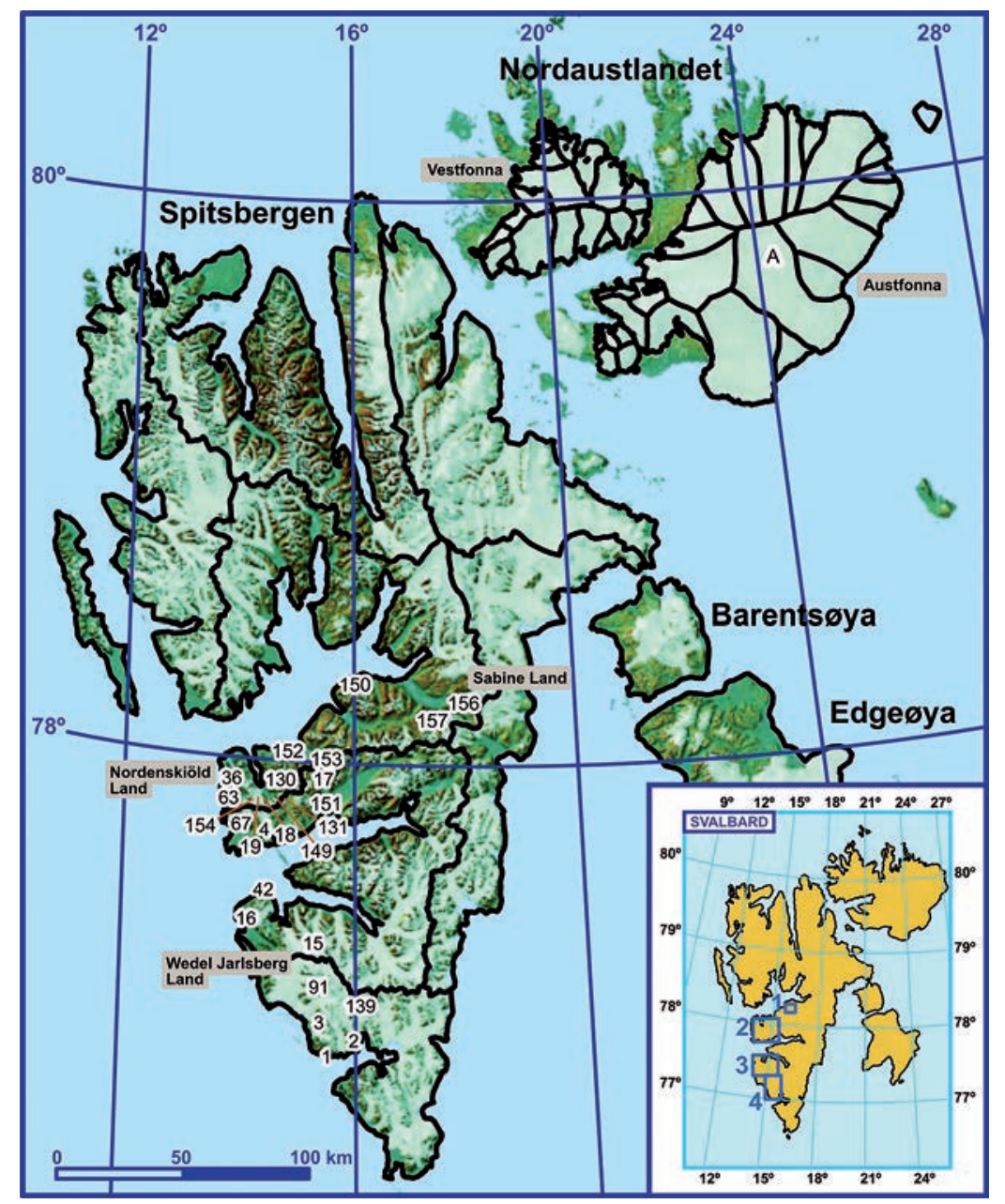

Figure 1. Location of the studied glaciers. Each glacier is numbered as in Table 1, using the IDs taken from the inventory of radio-echo sounded glaciers available online at http://svalglac.eu/. The ice caps of Austfonna and Vestfonna, in Nordaustlandet, are shown subdivided into their main drainage basins (black lines). The inset shows the location, within Svalbard, of the zones shown in the remaining figures. 


\section{Ground-penetrating radar campaigns}

We group below the radar campaigns by region. This regional grouping is in fact determined by the polar station or field camp that provided the logistic support for the fieldwork, related in turn to our foreign colleagues involved in the various campaigns.

\subsection{Nordenskiöld Land}

The fieldwork carried out in this region, located in central-western Spitsbergen (see Fig. 1), was logistically supported by the Scientific Station of the Institute of Geography of the Russian Academy of Sciences located in Barentsburg. These works were mostly done in cooperation with colleagues from the mentioned Institute (Y. Macheret, A. Glazovsky, I. Lavrentiev) and from the Institute of Industrial Research Akadempribor of the Uzbekian Academy of Sciences (E. Vasilenko).

The GPR data used in this study correspond to fifteen glaciers, all of them land terminating, with the exception of Fridtjovbreen, which is a tidewater glacier that experienced a surge in the 1990s (Murray et al., 2003). The GPR data were collected during several field campaigns between 1999 and 2013, all of them carried out during early spring, before the onset of strong surface melting. The different types of radar equipment, with their central frequencies and the total length of radar profiles, are summarized in Table 1. The layout of GPR profiles is displayed in Fig. 2, which also includes the 2007 glacier boundaries (Arendt et al., 2015; König et al., 2014), modified using Landsat images to match the area at the time when the glaciers were echo sounded. For the profiling, transmitting and receiving antennas were arranged coaxially along the profiling direction (parallel end-fire), to minimize direct coupling between antennas and also the reflections from the glacier side-walls, as most of the profiles were transverse to the glacier centre line (Navarro and Eisen, 2010). Further details about the radar campaigns can be found in Martín-Español et al. (2013), Martín-Español (2013) and Navarro et al. (2005).

\subsection{Wedel Jarlsberg Land}

The fieldwork carried out in this region, located in southern Spitsbergen (see Fig. 1), was logistically supported by the Polish Polar Station of Hornsund, and done in cooperation with colleagues from the University of Silesia (M. Grabiec) and the Institute of Geophysics of the Polish Academy of Sciences (D. Puczko).

The GPR data used in this study correspond to eight glaciers, whose location and outlines in 2007 (Arendt et al., 2015; König et al., 2014) are shown in Fig. 3. These glaciers have very different characteristics in terms of size, morphology and dynamics. Five of them are land terminating, while the remaining three are tidewater. One of them, Paierlbreen, experienced a surge during 1992-1996 (Błaszczyk et al., 2009). The GPR data were collected during several field campaigns between 2004 and 2013, using different radar equipments and frequencies which are summarized in Table 1 . The majority of the field campaigns were carried out in spring, before the onset of melting (about $95 \%$ of the profiles); the only exception was the campaign Ariebreen-2006, done during the summer. In general, basal 
Table 1. Listing of GPR campaigns carried out on each glacier, with specification of year, $G P R$ equipment used and its central frequency, and total length of radar profiles. All the GPR campaigns correspond to spring, except for Ariebreen-2006, done during the summer. An asterisk next to the GPR system indicates that the radar profiling was done from helicopter (all other were surface-based). References for the in-house built GPR systems are Vasilenko et al. (2002) for VIRL2, Berikashvili et al. (2006) for VIRL6 and Vasilenko et al. (2011) for VIRL7. Ramac refers to Ramac/GPR by Malå Geoscience. The glaciers are grouped by region, as shown in Figure 1. For each glacier, identified by its Id from the inventory of radio-echo sounded glaciers available online at http://svalglac.eu/ (same numbers as used in Figure 1), its area, volume, average thickness and maximum thickness, accompanied by their corresponding error estimates, are given. We note that some of the numbers could slightly differ from those given in earlier

publications, because of the use of improved interpolation algorithms or error estimates.

\begin{tabular}{|c|c|c|c|c|c|c|c|c|}
\hline Glacier & Id & Year & $\begin{array}{c}\text { Radar \& } \\
\text { central } \\
\text { frequency } \\
(\mathrm{MHz})\end{array}$ & $\begin{array}{c}\text { Length } \\
\text { profiles } \\
(\mathbf{k m})\end{array}$ & $\begin{array}{l}\text { Area } \\
\left(\mathbf{k m}^{2}\right)\end{array}$ & $\begin{array}{l}\text { Volume } \\
\left(\mathbf{k m}^{3}\right)\end{array}$ & $\underset{(\mathbf{m})}{\mathbf{H}_{\text {mean }}}$ & $\underset{(\mathbf{m})}{\mathbf{H}_{\max }}$ \\
\hline \multicolumn{9}{|c|}{ NORDENSKIÖLD LAND } \\
\hline Aldegondabreen & 36 & 1999 & VIRL2-15 & 40 & $7.18 \pm 0.29$ & $0.468 \pm 0.031$ & $65 \pm 7$ & $191 \pm 25$ \\
\hline Baalsrudbreen & 149 & 2013 & VIRL6-20 & 6 & $2.70 \pm 0.11$ & $0.077 \pm 0.004$ & $28 \pm 3$ & $98 \pm 5$ \\
\hline Blekumbreen & 150 & 2013 & VIRL6-20 & 14 & $2.16 \pm 0.09$ & $0.083 \pm 0.006$ & $38 \pm 4$ & $106 \pm 5$ \\
\hline Austre Dahlfonna & 154 & 2010 & VIRL6-20 & 8 & $2.55 \pm 0.10$ & $0.184 \pm 0.012$ & $72 \pm 7$ & $189 \pm 5$ \\
\hline Vestre Dahlfonna & 63 & 2012 & VIRL6-20 & 26 & $6.92 \pm 0.28$ & $0.259 \pm 0.025$ & $37 \pm 5$ & $151 \pm 6$ \\
\hline Erdmanbreen & 67 & 2012 & VIRL6-20 & 31 & $8.96 \pm 0.36$ & $0.823 \pm 0.041$ & $92 \pm 9$ & $190 \pm 5$ \\
\hline Fridtjovbreen & 4 & \begin{tabular}{|l|}
2005 \\
2012 \\
\end{tabular} & VIRL6/7-20 & 180 & $50.37 \pm 2.01$ & $5.433 \pm 0.246$ & $108 \pm 10$ & $265 \pm 16$ \\
\hline Gleditchfonna & 131 & 2011 & VIRL6-20 & 19 & $2.76 \pm 0.11$ & $0.076 \pm 0.005$ & $27 \pm 3$ & $79 \pm 4$ \\
\hline $\begin{array}{c}\text { Austre } \\
\text { Grønfjordbreen } \\
\end{array}$ & 18 & 2010 & VIRL6-20 & 53 & $8.41 \pm 0.34$ & $0.671 \pm 0.046$ & $80 \pm 8$ & $162 \pm 5$ \\
\hline $\begin{array}{c}\text { Vestre } \\
\text { Grønfjordbreen } \\
\end{array}$ & 19 & 2010 & $\begin{array}{c}\text { Ramac-100 } \\
\text { VIRL6-20 }\end{array}$ & 102 & $18.09 \pm 0.72$ & $1.775 \pm 0.094$ & $98 \pm 9$ & $215 \pm 5$ \\
\hline Marstanderbreen & 151 & 2013 & VIRL6-20 & 22 & $6.92 \pm 0.55$ & $0.233 \pm 0.017$ & $34 \pm 4$ & $125 \pm 4$ \\
\hline $\begin{array}{c}\text { Austre } \\
\text { Passfjellbreen }\end{array}$ & 152 & 2013 & VIRL6-20 & 18 & $5.13 \pm 0.41$ & $0.198 \pm 0.015$ & $39 \pm 4$ & $87 \pm 5$ \\
\hline $\begin{array}{c}\text { Vestre } \\
\text { Passfjellbreen }\end{array}$ & 153 & 2013 & VIRL6-20 & 9 & $2.32 \pm 0.19$ & $0.103 \pm 0.007$ & $44 \pm 5$ & $108 \pm 5$ \\
\hline Tavlebreen & 17 & $\begin{array}{l}2007 \\
2010\end{array}$ & \begin{tabular}{|c|} 
Step freq. 850 \\
Ramac-100/200 \\
VIRL6/7-20 \\
\end{tabular} & 58 & $8.02 \pm 0.32$ & $0.426 \pm 0.019$ & $53 \pm 5$ & $128 \pm 3$ \\
\hline Tungebreen & 130 & 2011 & VIRL6-20 & 13 & $2.88 \pm 0.12$ & $0.093 \pm 0.006$ & $32 \pm 3$ & $88 \pm 5$ \\
\hline \multicolumn{9}{|c|}{ WEDEL JARLSBERG LAND } \\
\hline Ariebreen & 1 & $\begin{array}{l}2006 \\
2007 \\
2009 \\
\end{array}$ & $\begin{array}{l}\text { Ramac-200 } \\
\text { Ramac-25 } \\
\text { Ramac-25 }\end{array}$ & 7 & $0.37 \pm 0.01$ & $0.010 \pm 0.001$ & $28 \pm 3$ & $78 \pm 3$ \\
\hline Hansbreen & 2 & \begin{tabular}{|l|}
2008 \\
2009 \\
2011 \\
\end{tabular} & $\begin{array}{c}\text { Ramac-25 } \\
\text { VIRL6/7 - } 20 \\
\text { VIRL7 - 20* }\end{array}$ & 90 & $64.16 \pm 2.57$ & $10.752 \pm 0.729$ & $168 \pm 18$ & $384 \pm 9$ \\
\hline Paierlbreen & 139 & \begin{tabular}{|l|}
2004 \\
2006 \\
2008 \\
2011 \\
\end{tabular} & $\begin{array}{c}\text { VIRL6 - } 20 \\
\text { VIRL6 - } 20 \\
\text { Ramac-25 } \\
\text { VIRL7-20* } \\
\end{array}$ & 73 & $99.19 \pm 3.97$ & $13.265 \pm 0.639$ & $134 \pm 12$ & $526 \pm 11$ \\
\hline Recherchebreen & 15 & $\begin{array}{l}2009 \\
2011 \\
\end{array}$ & $\begin{array}{l}\text { Ramac-25 } \\
\text { VIRL7-20 } \\
\end{array}$ & 51 & $136.31 \pm 5.45$ & $27.284 \pm 2.205$ & $200 \pm 23$ & $533 \pm 11$ \\
\hline
\end{tabular}




\begin{tabular}{|c|c|c|c|c|c|c|c|c|}
\hline Glacier & Id & Year & $\begin{array}{c}\text { Radar \& } \\
\text { central } \\
\text { frequency } \\
(\mathrm{MHz})\end{array}$ & $\begin{array}{c}\text { Length } \\
\text { profiles } \\
(\mathrm{km})\end{array}$ & $\begin{array}{l}\text { Area } \\
\left(\mathbf{k m}^{2}\right)\end{array}$ & $\begin{array}{c}\text { Volume } \\
\left(\mathbf{k m}^{3}\right)\end{array}$ & $\underset{(\mathbf{m})}{\mathbf{H}_{\text {mean }}}$ & $\underset{(\mathbf{m})}{\mathbf{H}_{\max }}$ \\
\hline Renardbreen & 16 & 2008 & Ramac-25 & 42 & $30.58 \pm 1.22$ & $5.141 \pm 0.224$ & $168 \pm 15$ & $348 \pm 8$ \\
\hline Scottbreen & 42 & 2009 & Ramac-25 & 10 & $4.71 \pm 0.19$ & $0.301 \pm 0.019$ & $64 \pm 7$ & $167 \pm 5$ \\
\hline $\begin{array}{c}\text { Austre } \\
\text { Torellbreen }\end{array}$ & 91 & \begin{tabular}{|l|}
2004 \\
2006 \\
2011 \\
2013 \\
\end{tabular} & $\begin{array}{l}\text { VIRL6-20 } \\
\text { VIRL6-20 } \\
\text { VIRL7-20* } \\
\text { Ramac-30 } \\
\end{array}$ & 170 & $140.99 \pm 5.64$ & $31.981 \pm 1.952$ & $227 \pm 20$ & $619 \pm 13$ \\
\hline Werenskioldbreen & 3 & 2008 & Ramac-25 & 37 & $26.60 \pm 1.06$ & $3.173 \pm 0.237$ & $119 \pm 13$ & $284 \pm 7$ \\
\hline \multicolumn{9}{|c|}{ SABINE LAND } \\
\hline Elfenbeinbreen & 156 & 2014 & VIRL7-25 & 105 & $39.96 \pm 3.20$ & $3.368 \pm 0.173$ & $85 \pm 9$ & $285 \pm 7$ \\
\hline Sveigbreen & 157 & 2014 & VIRL7-25 & 36 & $28.59 \pm 2.29$ & $2.004 \pm 0.107$ & $74 \pm 7$ & $212 \pm 5$ \\
\hline \multicolumn{9}{|c|}{ NORDAUSTLANDET } \\
\hline Austfonna & A & 2008 & VIRL6-20 & 880 & $8105 \pm 324$ & $2559 \pm 749$ & 319 & 587 \\
\hline
\end{tabular}

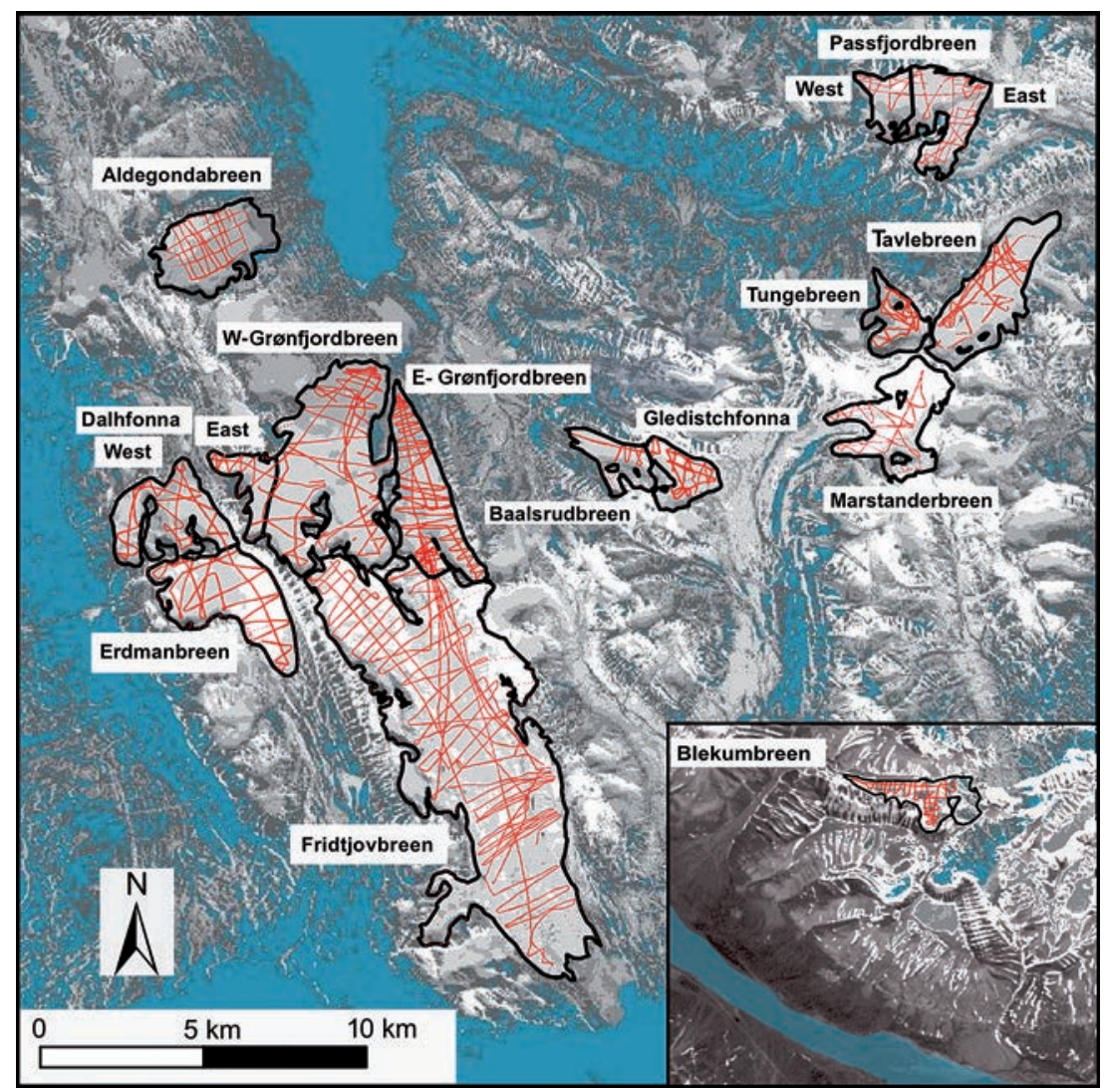

Figure 2. Location of the studied glaciers in Nordenskiöld Land and layout of GPR profiles. The location, within Svalbard, of the zones shown in this figure, is indicated in the inset of Figure 1

(blue rectangles numbered 2 and 1, for the main figure and the inset, respectively). 
reflections were easily observed in all measurements done with VIRL6 and VIRL7 $20 \mathrm{MHz}$ radar systems, while those done using $25 \mathrm{MHz}$ Ramac/GPR often did not allow clear bed detection for ice thickness above $\sim 300 \mathrm{~m}$. Figure 3 shows the distribution of the GPR profiles over the glacier surfaces. Although a sufficiently dense net of profiles covers most glaciers, yet some areas were not surveyed due to time limitations or the presence of crevasses (see more details on this in subsection 4.2). Further details about the radar campaigns can be found in Navarro et al. (2014), Lapazaran et al. (2013), Jania et al. (2005) and Grabiec et al. (2012). We note that Hansbreen-2003 radar campaign described in Jania et al. (2005), done during summer time, does not appear in Table 1 because we did not use its GPR data for ice-thickness estimates but for calculating the radio-wave velocity in ice.

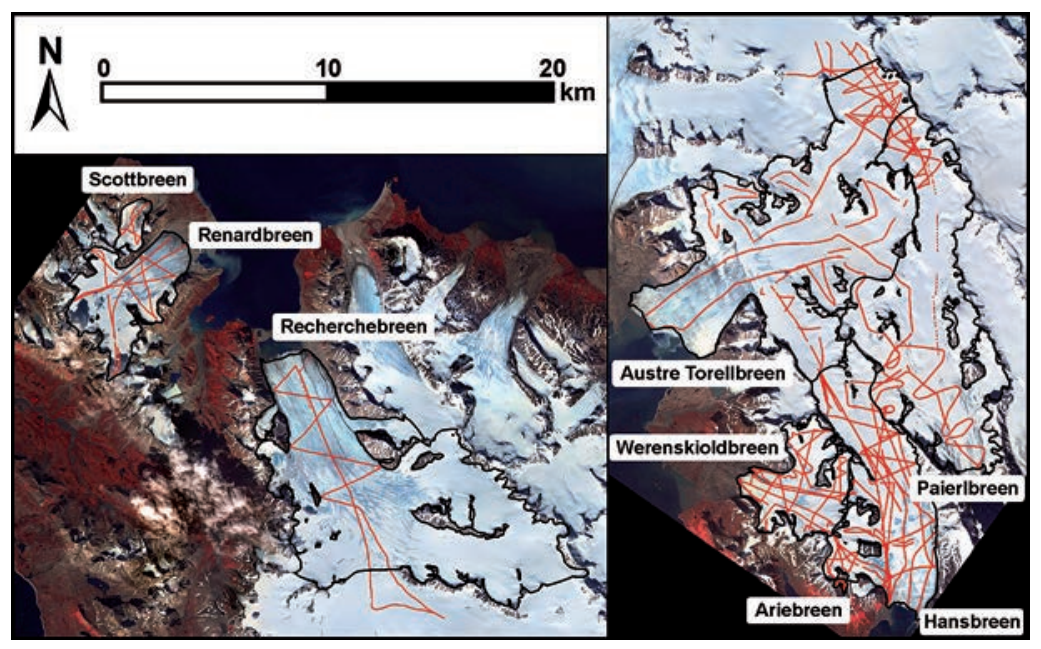

Figure 3. Location of the studied glaciers in Wedel Jarlsberg Land and layout of GPR profiles. The location, within Svalbard, of the zones shown in this figure, is indicated in the inset of Figure 1 (the left and right panels correspond to the blue squares numbered 3 and 4, respectively, in that inset).

\subsection{Sabine Land}

The fieldwork carried out in this region, located in the central part of eastern Spitsbergen (see Fig. 1), was logistically supported by a field camp at the forefront of Elfenbeinbreen, and was done in cooperation with colleagues from the University of Aachen (M. Möller, R. Möller) and the Technical University of Berlin (R. Finkelnburg).

The GPR data used in this study correspond to two glaciers, both land terminating, whose location is shown in Figure 1. The GPR campaign was carried out on 5-7 April 2014, before the onset of spring melting. The radar equipment used and the length of radar profiles are shown in Table 1. No detail of the layout of radar profiles and outlines of the glaciers are given here; these can be found in Fig. 1 of Navarro et al. (2015). We note that, while the Elfenbeinbreen basin was entirely surveyed, including its lateral 
tributaries, we were not able to survey the northern part of the Sveigbreen basin because of heavy crevassing. Hence, the surface area and the volume given for Sveigbreen in Table 1 are limited as shown in Fig. 1 of Navarro et al. (2015). Further details on the radar campaign can be found in the mentioned reference.

\subsection{Nordaustlandet}

The fieldwork carried out in this region, located in north-eastern Svalbard (see Fig. 1), corresponds to the ice cap of Austfonna, in the eastern part of Nordaustlandet (A in Figure 1). This fieldwork was done with the logistic support of a field camp at the summit of Austfonna, in cooperation with colleagues from the University of Oslo (J.O. Hagen, T. Dunse, T. Eiken).

Our GPR campaign was done in spring 2008, before the onset of spring melting, and included about $880 \mathrm{~km}$ of surface-based radar profiles across the main basins of Austfonna ice cap, shown in Fig. 1. The radar equipment used is indicated in Table 1. We note that the length of profiles given in Table 1 is restricted to our own GPR profiling. However, the area and volume correspond to the entire ice cap, with volume and average and maximum thickness determined from a total of $\sim 4800 \mathrm{~km}$ of airborne (except ours) radar profiles done in 1983 and 1986 by British-Norwegian researchers and in 2007 by Danish researchers. Further details on these radar campaigns can be found e.g. in Dowdeswell et al. (1984a) and Dunse (2011).

\section{Data processing, ice-thickness estimates and volume computations}

\subsection{GPR data processing}

Depending on the radar campaign, the GPR data were processed using the commercial software packages RadExPro, by GDS Production (Kulnitsky et al., 2000), and ReflexW (Sandmeier Scientific Software, 2012). In general, the main processing steps consisted of bandpass filtering, normal move-out correction, amplitude correction, deconvolution and migration. For Ramac/GPR data, predictive deconvolution was used (e.g. Yilmaz, 2001), whereas for VIRL GPR data deconvolution was in general not used because our pulse duration is small ( $25 \mathrm{~ns})$ and thus there is no need to shorten it. The migration algorithm applied was Stolt 2D F-K (e.g. Yilmaz, 2001).

For the time-to-thickness conversion we used, for each glacier, a constant radio-wave velocity (RWV), which varied form glacier to glacier between 0.166 and $0.170 \mathrm{~m} \mathrm{~ns}^{-1}$. The choice of the RWV used for each glacier was made taking into account its geographical location, average thickness, thermal structure (cold, polythermal) and the available previous common-midpoint measurements on Svalbard (Glazovskiy et al., 1991; Jania et al. 2005; Navarro et al., 2005). We also took into account the fact that the GPR measurements were mostly made in early spring, before the onset of melting. Navarro et al. (2014) have shown that the use of a constant radio-wave velocity, if selected on the basis of regional column-averaged RWV measurements and taking into account the glacier size and morphology, has little influence on the volume and average ice-thickness estimates. 
Further details on the GPR radar data processing and RWV selected can be found in Martín-Español et al. (2013), for Nordenskiöld Land glaciers, Navarro et al. (2014), for Wedel Jarlsberg Land glaciers, Navarro et al. (2015), for Sabine Land glaciers, and Dunse (2011), for Austfonna ice cap in Nordaustlandet.

\subsection{Ice thickness estimates and volume computations for individual glaciers}

Ice-thickness data were interpolated into a regular grid using anisotropic ordinary kriging with a spherical variogram (e.g. Cressie, 1993). We adjusted the 2007 glacier boundaries (Arendt et al., 2015; König et al., 2014) to the year of the GPR measurements using satellite imagery (mostly Aster and Landsat 7 images) to clip the gridded icethickness map. The resulting ice-thickness distributions are shown in figures 4 and 5 for Nordenskiöld Land and Wedel Jarlsberg Land glaciers, respectively. Those for Sabine Land are shown in Figure 2 of Navarro et al. (2015), while those for Austfonna ice cap in Nordaustlandet are presented in Figure 5.5c of Dunse (2011).

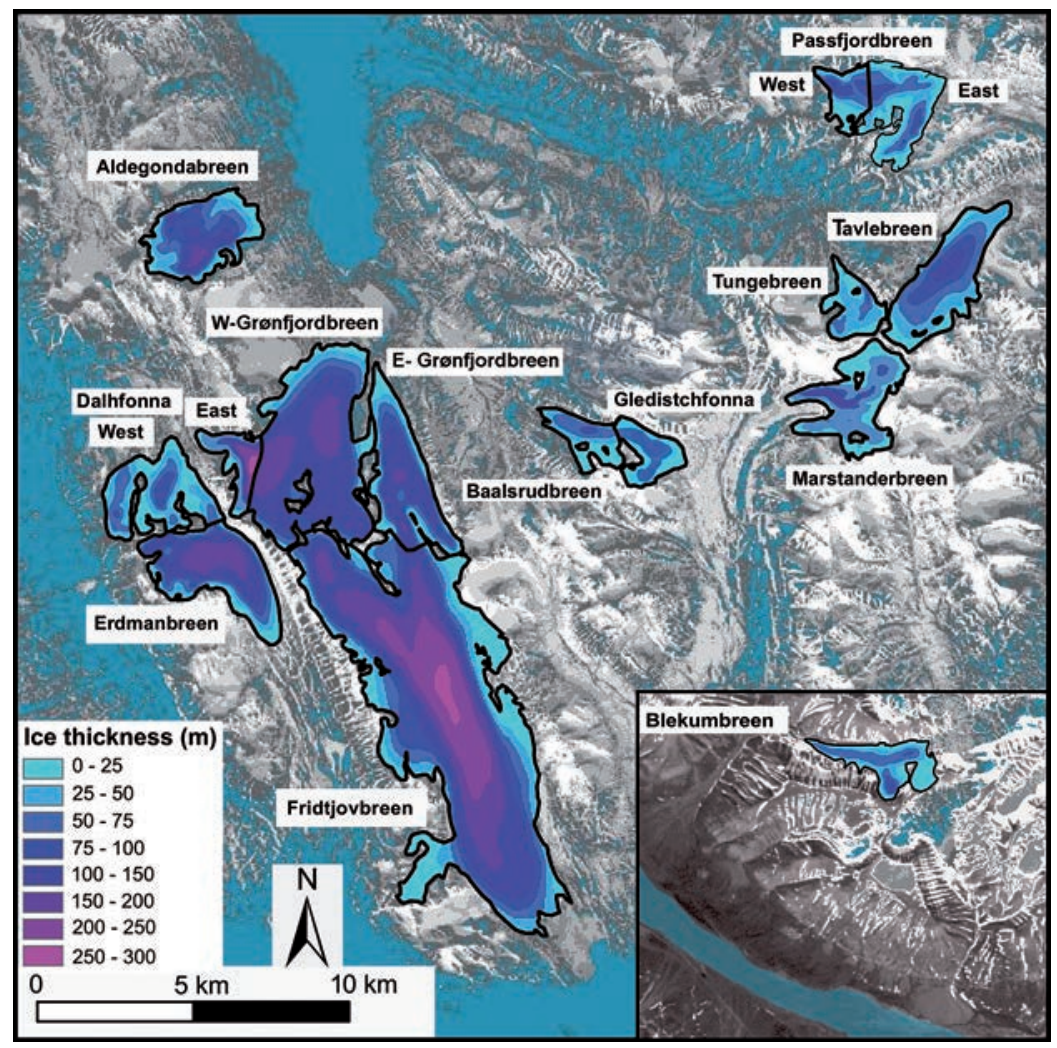

Figure 4. Ice-thickness of ten of the studied glaciers in Nordenskiöld Land. The location, within Svalbard, of the zones shown in this figure, is indicated in the inset of Figure 1 (blue rectangles numbered 2 and 1 , for the main figure and the inset, respectively). 


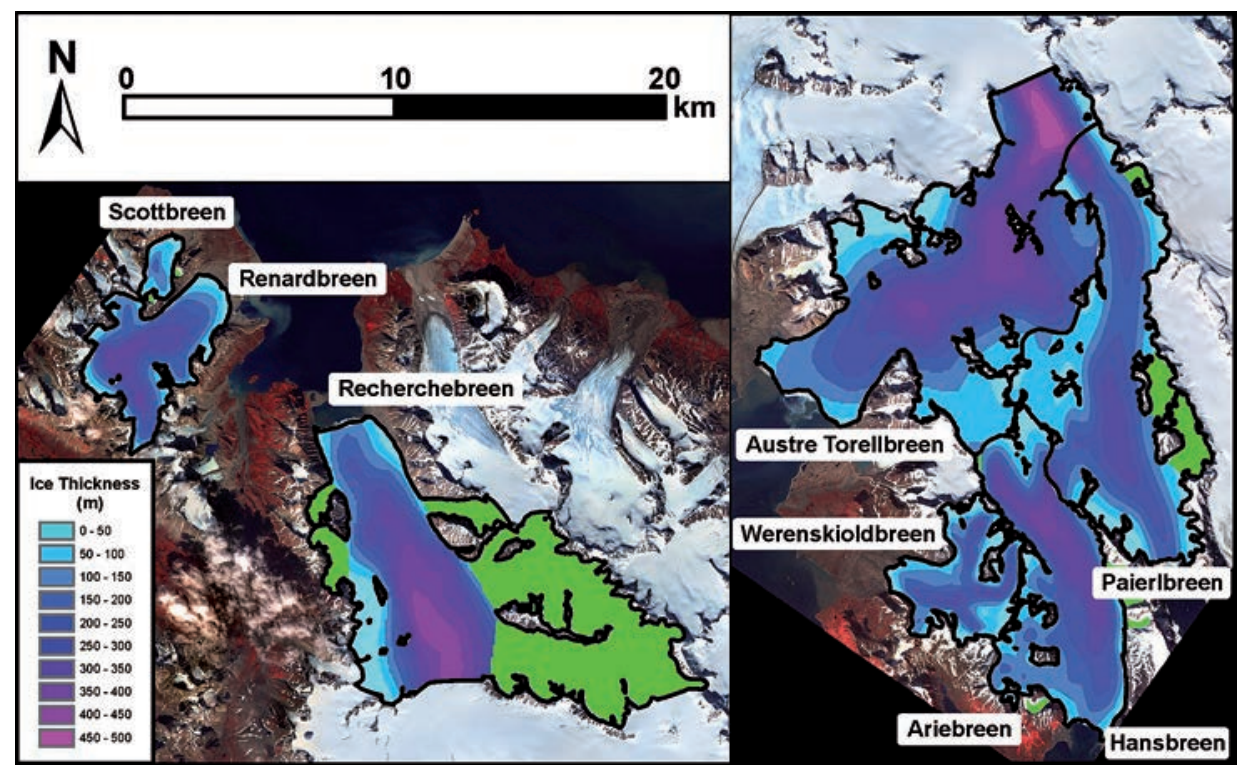

Figure 5. Ice-thickness maps of the studied glaciers in Wedel Jarlsberg Land. The location, within Svalbard, of the zones shown in this figure, is indicated in the inset of Figure 1 (the left and right panels correspond to the blue squares numbered 3 and 4 , respectively, in that inset).

The green-coloured areas represent unsurveyed tributary glaciers, for which the volume was estimated as described in section 3.2 of Navarro et al. (2014).

Glacier volume was obtained summing up the products, at each grid cell, of the cell thickness times the cell area. Because one of our goals was to calculate the ice volume of entire glacier basins, for glaciers that included unsurveyed tributary glaciers (green-coloured zones in Fig. 5), we circumvented the lack of GPR profiles by providing approximate ice-thickness data for these unsurveyed areas, and calculating their ice volume, following the technique described in Section 3.2 of Navarro et al. (2014). The surface area for each of the surveyed glaciers, and the results for their calculated volumes, accompanied by their corresponding error estimates (see details in next subsection), are presented in Table 1. We note that, for the ten Nordenskiöld Land glaciers surveyed before 2013, the glacier volumes presented here slightly differ from those reported in Martín-Español et al. (2013), because the gridded ice-thickness data were interpolated, in the latter study, using the Gridfit routine available for Matlab (D'Errico, 2006).

\subsection{Estimates of errors in volume}

Ice volume estimations are affected by errors from various sources which are discussed e.g. in Section 3.4 of Navarro et al. (2014). In summary, our procedure for estimating the error in glacier volume takes into account: 1) the point-dependent ice thickness errors of the GPR data (including the GPS-positioning error, the error in timing and the error in radio-wave velocity); 2) the interpolation error at every gridcell; and 3) 
the volume error stemming from the uncertainty in the glacier boundary delineation. We estimate the interpolation error by using a modified ordinary kriging routine whereby the uncertainty in thickness at a given gridpoint is calculated relating the cross-validation errors with the distance to the nearest GPR measurement. We propagate the data errors to the gridpoints using the same weights adopted in the kriging interpolation procedure. Finally, the errors obtained at each gridpoint are optimally combined and averaged, considering the autocorrelation length scale of the ice thickness, to obtain the volume error. Further details are provided by Martín-Español (2013).

\subsection{Extrapolation to the volume of the entire set of Svalbard glaciers}

Two alternative approaches could be followed to calculate the total volume of the entire set of Svalbard glaciers and ice caps: the use of volume-area (V-A) scaling relationships (e.g. Grinsted, 2013) and the use of physically-based methods relating the ice-thickness distribution with the glacier topography, mass balance and dynamics (Huss and Farinotti, 2012).

Given the rather large set of available volumes for individual glaciers, calculated with a rather good accuracy from GPR-retrieved ice-thickness data, we chose the simpler $\mathrm{V}-\mathrm{A}$ approach. However, the set of glacier volumes presented in this paper ( 25 glaciers, in addition to Austfonna ice cap) is still insufficient for calibrating a proper regional V-A scaling relationship. Arecent study (Farinotti and Huss, 2013) has shown that, in estimating the accuracy with which the total volume of a glacier population can be recovered from a $\mathrm{V}$-A relationship, the volume measurement uncertainty plays a secondary role compared with the sizes of both the total population and the sample, provided that the latter is sufficiently large. Following this idea, in Martín-Español et al. (2015) we extended the calibration dataset up to a total of 60 volume-area pairs, by including volumes of glaciers echo sounded by other authors, having a net of GPR profiles covering most of the glacier basin and dense enough to allow for a sufficiently accurate volume estimate. Of the 60 available glacier volumes, 36 (the 25 glaciers in Table 1 -excluding Austfonna ice capand 11 additional ones echo sounded by other researchers) were calculated by us from the original GPR-retrieved ice-thickness data and have an accuracy in general better than $10 \%$ (often just around 5\%). 6 other glacier volumes were gathered from the literature and have an accuracy better than $20 \%$ according to the original sources. Finally, we added to our calibration dataset 18 additional entries extracted from the catalogue of glacier volumes of the whole world (Cogley, 2012), reported in Grinsted (2013), for which we assume a volume accurate to better than 30\% (Martín-Español, 2013). All of these additional entries correspond to Scott Polar Research Institute-Norsk Polarinstitutt (Dowdeswell et al., 1984b) and Soviet (Macheret and Zhuravlev, 1982) airborne radioecho soundings in the 1970s and 1980s, which only covered the glacier centre lines, and thus their volumes were computed from the central flowline ice-thickness, assuming a parabolic cross-section, as described in Martín-Español (2013). We note that we excluded the glaciers with doubtful bed reflection interpretation from Soviet flights discussed by Dowdeswell et al. (1984b) and later acknowledged by Macheret et al. (1984). Further 
details on the calibration dataset, in particular regarding its comparison with the total population of Svalbard glaciers, can be found in Martín-Español et al. (2015).

The above calibration data set were used to determine the free parameters $c$ and g of a volume-area scaling relationship of the type $V=c A^{\gamma} V=c A^{\gamma}$, with $A$ the glacier area and $V$ the glacier volume. Two different regression techniques were used for calibrating the V-A relationship. Once calibrated, these two V-A relationships were applied to estimate the volume of the dataset of 1562 individual glacier basins in Svalbard and Jan Mayen, excluding the glacier basins of Austfonna and Vestfonna ice caps in Nordaustlandet. The latter include 53 glacier basins, which, if added, would make the total of 1615 glacier basins of Svalbard and Jan Mayen included in the Randolph Glacier Inventory V3.2 (Pfeffer et al., 2014). The details are given in Martín-Español et al. (2015). The resulting total volume of Svalbard and Jan Mayen glaciers, excluding those in Nordaustlandet, are $3745 \pm 767$ and $3652 \pm 891 \mathrm{~km}^{3}$, depending on the regression technique used.

The volumes of Austfonna and Vestfonna were calculated independently, directly from the GPR-retrieved ice-thickness data, because the V-A scaling relationships for glaciers and ice caps are expected to differ significantly, and for Svalbard we have an insufficient number of ice caps to determine a separate regional V-A relationship for ice caps. Moreover, using a V-A relationship for ice caps would make no sense, since the glacier volume determined from ice-thickness data is expected to be much more accurate than a volume determined from V-A scaling. For Austfonna and Vestfonna we took the volumes calculated by Pettersson et al. (2011) and Martín-Español (2013), which are $2559 \mathrm{~km}^{3}$ (Austfonna) and $442 \mathrm{~km}^{3}$ (Vestfonna), with respective relative errors of 3\% and 7\%, estimated by Martín-Español (2013). This gives a total volume for Nordaustlandet's ice caps of $3001 \pm 81 \mathrm{~km}^{3}$. Added to the volumes of the rest of Svalbard and Jan Mayen glaciers given above, this produces a total volume for the glaciers and ice caps of Svalbard and Jan Mayen of $6746 \pm 771$ or $6653 \pm 895 \mathrm{~km}^{3}$, depending on the choice of regression technique, averaging $6700 \pm 835 \mathrm{~km}^{3}$, which is our best estimate for the total volume of the glaciers and ice caps of Svalbard and Jan Mayen.

\section{Discussion and conclusions}

The individual areas, volumes, and average thickness show large spans, of 0.37-140.99 km², 0.01-31.98 km³ and 27-227 m, respectively (excluding Austfonna). The maximum ice thickness, reaching $619 \pm 13 \mathrm{~m}$, is found in the northernmost part of Austre Torellbreen, near its ice divide with Vestre Torellbreen, within the Amundsenisen ice field.

These estimates of individual volumes of glaciers have a double interest. On one hand, they can be used, as described in this paper, to calibrate volume-area scaling relationships, either global or regional, than can then be applied to estimate the total volume of larger population of glaciers, at a regional or even at a global level. In fact, is in these cases when the V-A relationships are most useful. The reason is that the volume estimates based on V-A scaling can involve very large errors when applied to individual glaciers, though the errors are much lower, because of statistical compensation, when 
applied to large sets of glaciers. According to Meier and others (2007), estimated volume errors for individual glaciers could exceed $50 \%$ but these uncertainties are reduced to $25 \%$ for an ensemble of glaciers. Consistent with these results, a recent study by Adhikari and Marshall (2012), using a V-A relationship based on a sample of 280 synthetic random mountain glaciers, has shown that, when estimating the volumes for all individual glaciers in their ensemble, the average glacier volume error is small (2.8\%), with a mean absolute error of $18.3 \%$.

On the other hand, the glacier volumes calculated form GPR-retrieved ice-thickness data are also useful to calibrate the free parameters of the physically-based models relating the ice-thickness distribution with the glacier topography, mass balance and dynamics. These models are the alternative to the V-A relationships to calculate the volume of large populations of glaciers. Moreover, as mentioned earlier, these two families of methods are a usual tool for regional and global projections of mass losses from glaciers, and corresponding sea-level rise, in response to climate scenarios. Finally, the estimate of the total volume of the entire population of glaciers on Earth provides the knowledge of its potential contribution to sea-level rise and allows predicting for how long glaciers will continue to be the largest contributors to sea-level rise.

Our best estimate of Svalbard ice volume is $6700 \pm 835 \mathrm{~km}^{3}$. In terms of sea-level equivalent, assuming an oceanic area of $3.62 \times 10^{8} \mathrm{~km}^{2}$ and a glacier ice density of $900 \mathrm{~kg} \mathrm{~m}^{-3}$, our volume estimate corresponds to a total potential contribution to sea-level rise of $17 \pm 2 \mathrm{~mm}$ SLE. This volume estimate is in the low range of those published in the literature, which span a range of $5229-9690 \mathrm{~km}^{3}$ (see e.g. Table 1 of Martín-Español et al., 2015), but still substantially higher than the lowermost estimate by Grinsted (2013), of $5229 \mathrm{~km}^{3}$.

\section{Acknowledgements}

This study has been supported by grant CTM2014-56473-R from the Spanish National Plan for R\&D.

\section{References}

Adhikari, S., Marshall, S.J. 2012. Glacier volume-area relation for high-order mechanics and transient glacier states. Geophysical Research Letters 39 (16), L16505. Doi: 10.1029/2012GL052712.

Arctic Climate Impact Assessment (ACIA) 2005. Arctic Climate Impact Assessment: scientific report. Cambridge University Press, Cambridge.

Arendt, A. et al. 2015. Randolph Glacier Inventory (RGI) 5.0. Available at: http://www.glims.org/ RGI/rgi50_dl.html (last access: 31/12/2015).

Berikashvili, V., Vasilenko, E., Macheret, Y.Y., Sokolov, V.G. 2006. Ul'sny radar dlya zondirovaniya lednikov s opticheskim kanalom sinkhronizatsii i tifrovoy brabotkoy signalov [Monopulse radar for sounding of glaciers with optical synchronization channel and digital processing of signals]. Radiotekhnika 9, 52-57 [in Russian].

Błaszczyk, M., Jania, J., Hagen, J.O. 2009. Tidewater glaciers of Svalbard. Polish Polar Research $30(2), 85-142$. 
Cogley, J.G. 2012. The future of the world's glaciers. In Henderson-Sellers, A., McGuffie, K. (eds.), The future of the world's climate. Elsevier, Waltham, MA, pp. 197-222.

Cressie, N. 1993. Statistics for Spatial Data, Revised edition. Wiley, New York, 900 pp.

Dowdeswell, J.A., Drewry, D.J., Liestøl, O., Orheim, O. 1984a. Airborne radio echo sounding of sub-polar glaciers in Spitsbergen. Nor. Polarinst. Skr. 182.

Dowdeswell, J.A., Drewry, D.J., Liestøl, O., Orheim, O. 1984b. Radio echo-sounding of Spitsbergen glaciers: problems in the interpretation of layer and bottom returns. Journal of Glaciology 30 (104), 16-21.

Dunse, T. 2011. Glacier dynamics and subsurface classification of Austfonna, Svalbard: inferences from observations and modelling. $\mathrm{PhD}$ thesis, University of Oslo.

D’Errico, J. 2006. Surface fitting using gridfit. MATLAB Central File Exchange. Available at: http://www.mathworks.com/matlabcentral/fileexchange/8998-surface-fitting-using-gridfit (last access: 31/12/2015).

Farinotti, D., Huss, M. 2013. An upper-bound estimate for the accuracy of glacier volume-area scaling. Cryosphere 7 (6), 1707-1720. Doi: 10.5194/tc-7-1707-2013.

Glazovskiy, A.F., Macheret, Y., Moskalevskiy, M.Y., Jania, J. 1991. Tidewater glaciers of Spitsbergen. In Glaciers-Ocean-Atmosphere Interactions, Proceedings of the International Symposium, St. Petersburg, 1990, IAHS Publ. 208, pp. 229-239.

Grabiec, M., Jania, J., Puczko, D., Kolondra, L., Budzik, T. 2012. Surface and Bed Morphology of Hansbreen, a Tidewater Glacier in Spitsbergen. Polish Polar Research 33 (2), 112-138. Doi: 10.2478/v10183-012-0010-7.

Grinsted, A. 2013. An Estimate of Global Glacier Volume. Cryosphere 7 (1), 141-151. Doi: 10.5194/tc-7-141-2013.

Huss, M., Farinotti, D. 2012. Distributed ice thickness and volume of all glaciers around the globe. Journal of Geophysical Research 117 (F4). Doi: 10.1029/2012JF002523.

Huss, M., Hock, R. 2015. A new model for global glacier change and sea-level rise. Frontiers in Earth Sciences 3 (54), 1-22. Doi: 10.3389/feart.2015.00054.

Jania, J., Macheret, Y.Y., Navarro, F.J., Glazovskiy, A.F., Vasilenko, E.V., Lapazaran, J., Glowacki, P., Migala, K., Balut, A., Piwowar, B.A. 2005. Temporal changes in the radiophysical properties of a polythermal glacier in Spitsbergen. Ann. Glaciol. 42, 125-134.

König, M., Nuth, C., Kohler, J., Moholdt, G., Pettersson, R. 2014. A digital glacier database for Svalbard. In Raup, B.H., Kääb, A., Bishop, M.P., Leonard, G.J., Kargel, J.S. (eds.), Global Land Ice Measurements from Space. Springer-Verlag, Berlin and Heidelberg, 876 pp. Doi: 10.1007/978-3-540-79818-7.

Kulnitsky, L.M., Gofman, P.A., Tokarev, M. 2000. Matematicheskaya obrabotka dannykh georadiolokatsii i systema RADEXPRO 281 [Mathematical processing of georadar data and RADEXPRO system]. Razv. Okhrana Nedr. 21, 6-11 [In Russian].

Lapazaran, J., Petlicki, M., Navarro, F., Machío, F., Puczko, D., Glowacki, P., Nawrot, A. 2013. Ice volume changes 1936-1990-2007 and ground penetrating radar studies of Ariebreen, Hornsund, Spitsbergen. Polar Research 32, 11068. Doi: 10.3402/polar.v32i0.11068.

Macheret, Y., Zhuravlev, A.B., Bobrova, L.I. 1984. Tolshchina, podlednyy rel'yef i ob"yem lednikov Shpitsbergena po dannym radiozondirovan-iya [Thickness, subglacial relief and volume of Svalbard glaciers from radio echo-sounding data]. Mater. Glyatsiol. Issled. [Data Glaciol. Studies] 51, 49-63 [in Russian with English summary].

Martín-Español, A. 2013. Estimate of the total ice volume of Svalbard glaciers and their potential contribution to sea-level rise. $\mathrm{PhD}$ Thesis, Universidad Politécnica de Madrid.

Martín-Español, A., Vasilenko, E.V., Navarro, F.J., Otero, J., Lapazaran, J.J., Lavrentiev, I., Macheret, Y.Y., Machío, F. 2013. Radio-echo sounding and ice volume estimates of western 
Nordenskiöld Land glaciers, Svalbard. Annals of Glaciology 54 (64), 211-217. Doi: 10.3189/2013AoG64A109.

Martín-Español, A., Navarro, F.J., Otero, J., Lapazaran, J.J., Blaszczyk, M. 2015. Estimate of the total volume of Svalbard glaciers, and their potential contribution to sea-level rise, using new regionally-based scaling relationships. Journal of Glaciology 61 (225), 29-41. Doi: 10.3189/2015JoG14J159.

Meier, M.F., Dyurgerov, M.B., Rick, U.K., O’Neel, S., Pfeffer, W.T., Anderson, R.S., Anderson, S.P., Glazovsky, A.F. 2007. Glaciers dominate eustatic sea-level rise in the 21st century. Science 317 (5841), 1064-1067. Doi: 10.1126/science.1143906.

Murray, T., Luckman, A., Strozzi, T., Nuttall, A.M. 2003. The initiation of glacier surging at Fridtjovbreen, Svalbard. Annals of Glaciology 36, 110-116. Doi: $10.3189 / 172756403781816275$.

Navarro, F., Eisen, O. 2010. Ground-penetrating radar in glaciological applications. In Pellikka, P., Rees, W.G. (eds.). Remote sensing of glaciers: techniques for topographic, spatial and thematic mapping of glaciers. Taylor \& Francis, London, pp. 195-229.

Navarro, F.J., Glazovskiy, A.F., Macheret, Y., Vasilenko, E.V., Corcuera, M.I., Cuadrado, M.L. 2005. Ice volume changes 1936-1990 and structure of Aldegondabreen, Spitsbergen. Annals of Glaciology 42, 158-162.

Navarro, F.J., Martín-Español, A., Lapazaran, J.J., Grabiec, M., Otero, J., Vasilenko, E.V., Puczko, D. 2014. Ice volume estimates from ground-penetrating radar surveys, Wedel Jarlsberg Land glaciers, Svalbard. Arctic, Antarctic, and Alpine Research 46 (2), 394-406. Doi: 10.1657/1938-4246-46.2.394.

Navarro, F.J., Möller, R., Vasilenko, E., Martín-Español, A., Finkelnburg, R., Möller, M. 2015. Ice thickness distribution and hydrothermal structure of Elfenbeinbreen and Sveigbreen, Eastern Spitsbergen, Svalbard. Journal of Glaciology 61 (229), 1015-1018. Doi: 10.3189/2015JoG15J141.

Pettersson, R., Christoffersen, P., Dowdeswell, J.A., Pohjola, V.A., Hubbard, A., Strozzi, T. 2011. Ice thickness and basal conditions of Vestfonna Ice Cap, eastern Svalbard. Geografiska Annaler A, 93 (4), 311-322. Doi: 10.1111/j.1468-0459.2011.00438.x.

Pfeffer, W.T., Arendt, A.A., Bliss, A., Bolch, T., Cogley, J.G., Gardner, A.S., Hagen, J.O., Hock, R., Kaser, G., Kienholz, C., Miles, E.S., Moholdt, G., Mölg, N., Paul, F., Radić, V., Rastner, P., Raup, B.H., Rich, J., Sharp, M. 2014. The Randolph Glacier Inventory: a globally complete inventory of glaciers. Journal of Glaciology 60 (221), 537-552. Doi: 10.3189/2014JoG13J176.

Radić, V., Hock, R. 2010. Regional and global volumes of glaciers derived from statistical upscaling of glacier inventory data. Journal of Geophysical Research 115 (F1). Doi: 10.1029/2009JF001373.

Radić, V., Bliss, A., Beedlow, A.C., Hock, R., Miles, E., Cogley, J.G. 2014. Regional and global projections of twenty-first century glacier mass changes in response to climate scenarios from global climate models. Climate Dynamics 42 (1-2), 37-58. Doi: 10.1007/s00382-0131719-7.

Sandmeier Scientific Software. 2012. ReflexW. Available at: http://www.sandmeier-geo.de/ (last access: 31/12/2015)

Stocker, T.F. (ed.) 2013. Climate change 2013: The physical science basis. Contribution of Working Group I to the Fifth Assessment Report of the Intergovernmental Panel on Climate Change. Cambridge University Press, Cambridge and New York, pp. 1-9.

Vasilenko, E.V., Sokolov, V.A., Macheret, Y., Glazovskiy, A.F., Cuadrado, M.L., Navarro, F.J. 2002. A digital recording system for radioglaciological studies. Bulletin of the Royal Society N.Z. 35, 611-618. 
Vasilenko, E., Machío, F., Lapazaran, J., Navarro, F.J., Frolovskiy, K. 2011. A compact lightweight multipurpose ground-penetrating radar for glaciological applications. J. Glaciol. 57 (206), 1113-1118. Doi: 10.3189/002214311798843430.

Ya, V., Zhuravlev, A.B. 1982. Radio echo-sounding of Svalbard glaciers. Journal of Glaciology 28 (99), 295-314.

Yilmaz, O. 2001. Seismic Data Analysis: Processing, Inversion and Interpretation of Seismic Data (Vols. 1 \& 2). Society of Exploration Geophysicists, Tulsa, Oklahoma, 2027 pp. 